\title{
Density and Morphometry of Overall Myenteric Neurons Population from the Duodenum of Diabetic Rats (Rattus norvegicus) under Ascorbic Acid Supplementation
}

\author{
Densidad y Morfometría de la Población Total de Neuronas Mientéricas del \\ Duodeno de Ratones Diabéticos (Rattus norvegicus) Tratados con Ácido Ascórbico
}

Marli Aparecida dos Santos Pereira; Ana Paula Liberati; Ivan Domicio da Silva Souza \& Jacqueline Nelisis Zanoni

PEREIRA, M. A. S.; LIBERATI, A. P.; SOUZA, I. D. S. \& ZANONI, J. N. Density and morphometry of overall myenteric neurons population from the duodenum of diabetic rats (Rattus norvegicus) under ascorbic acid supplementation. Int. J. Morphol., 27(2):413418, 2009.

SUMMARY: The objective of this work was to evaluate the overall myenteric neurons population from the duodenum of adult streptozotocin-induced diabetic rats supplemented with ascorbic acid (AA), a potent antioxidant. Fifteen 90-day-old rats were divided in groups: control (C), diabetic (D), diabetic treated with ascorbic acid (DA). After 120 days of experimental period duodenums were resected and processed as whole-mount preparations according to Giemsa's technique, which allowed us to evaluate neuronal density in an area of $8.96 \mathrm{~mm}^{2}$ and measure the area of 500 neuronal cell bodies per group. It was observed a $32.55 \%$ reduction in neuronal density of group D when compared to group C $(\mathrm{p}<0.05)$. The density of spared neurons in group DA, in relation to group D, was not statistically different in this experimental model. No significant differences were found in neuronal areas when groups C and D or group D and DA were compared $(p>0.05)$. These results lead us to conclude that the density of overall myenteric neurons population from the duodenum was reduced in diabetic rats (D), when compared to its control (C); and that diabetic rats supplemented with AA (DA) did not have their neuronal density preserved when compared to diabetic animals (D).

KEY WORDS: Ascorbic acid; Diabetes mellitus; Duodenum; Oxidative stress.

\section{INTRODUCTION}

The enteric nervous system (ENS) controls many gastrointestinal functions, such as motility, gastric secretions and transport. ENS is composed of two plexuses, one external, in which ganglia are situated between longitudinal and circular muscular layers, designated myenteric plexus; and another internal, in which ganglia are situated in submucosa, designated submucous plexus (Gershon, 1981; Furness \& Costa, 1987).

During diabetes, small intestine exhibits numerous morphological and functional alterations. Our group with research focus on myenteric neurons verified that several intestinal segments of diabetic rats suffered reduction in number and alterations in size, as demonstrated in colon (Romano et al., 1996; Furlan et al., 2002), in cecum (Zanoni et al., 1997) and in the small intestine (Hernandes et al., 2000).
Gastrointestinal neuropathy is one of the most common diabetes-related complications. Diabetic neuropathy originates from a combination of microvascular and neuronal deficits. Neuronal injury is a consequence of sorbitol, supplied by the metabolism of intracellular glucose excess in non-insulin dependent tissues through the activity of aldose reductase. High concentrations of sorbitol lead to an increase in intracellular osmolarity, causing edema, neuronal lesion and consequent reduction in nervous conduction velocity (Hosking et al., 1978). Glucose in excess also strongly intensifies the metabolic ways resulting in an elevated production of free radicals and low capacity of free radicals detoxification, culminating in oxidative stress in the peripheric nervous system and contributing for the development of diabetic neuropathy (Vincent et al., 2004).

Department of Morphophysiological Sciences, Universidade Estadual de Maringá, Paraná, Brazil. 
While total glycemic control is not achieved, therapies based on antioxidant substances seem to be promissory in preventing neuropathies, as well as diabetes complications. Consulted literature shows that ascorbic acid plays a relevant role in the treatment of diabetes neurological complications, since it reduces the concentration of sorbitol by inhibiting aldose reductase, besides reducing capillary fragility and oxidative stress (Yue et al., 1989; Cunningham et al., 1994; Cotter et al., 1995; Will \& Byers, 1996).

Currently, part of our research group has submitted diabetic animals to antioxidant substances therapy, like vitamins C and E. Among these studies, Zanoni et al. (2003) observed in the ileum that nitrergic neurons cell bodies areas of diabetic rats treated with AA, were inferior to the ones in diabetic rats not treated. We also verified that AA supplementation prevented the loss of a myenteric neurons subpopulation (NADH-diaphorase positive neurons) in the duodenum of diabetic rats (Pereira et al., 2006). Considering these previous researches, our objective was to evaluate if AA has the same protective effect on overall myenteric neurons population from the duodenum of adult streptozotocin-induced diabetic rats.

\section{MATERIAL AND METHOD}

Fifteen 90-day-old Wistar strain male rats (Rattus norvegicus), obtained from the Central Biotery of Universidade Estadual de Maringá, were used and divided in three groups: control (C) - five normoglycemic animals, diabetic (D) - five animals that received $35 \mathrm{mg}$ of streptozotocin per kg body weight endovenously (penile vein) and diabetic treated with ascorbic acid (DA) - five animals that received $35 \mathrm{mg}$ of streptozotocin per $\mathrm{kg}$ body weight endovenously (penile vein) and were treated with ascorbic acid ( $1 \mathrm{~g} / \mathrm{L} /$ day $)$. Animals in group D and DA were submitted to previous 14-hours fast and then had streptozotocin injected.

Animals were killed after 120 days of experimental period. In that day, animals were weighted and anesthetized with thiopental (40 mg/kg body weight). Blood was sampled by cardiac punction for determination of glycemia (glucose oxidase method) and glycated hemoglobin.

The segments of duodenum from the animals in each group were resected immediately after pylorus and duodenojejunal junction and submitted to whole-mount preparations colored according to Giemsa's method (Barbosa, 1978). In order to accomplish that, segments were washed in saline solution; inflated with Giemsa's fixative solution to avoid tissue retraction; fixated in the same solution; microdissected under transilluminated stereomicroscope removing mucosa and submucosa; colored by Giemsa's method, based on methylene blue; dehydrated in increasing series of alcohols; clarified in xylol and mounted between slide and cover glass in Permount ${ }^{\circledR}$.

Myenteric neurons cell bodies colored by Giemsa's staining, found between external longitudinal an internal circular muscular layers from the duodenum, were counted in light microscope (Leica DM RX), 40x objective, in the intermediate region $\left(60^{\circ}-120^{\circ}, 240^{\circ}-300^{\circ}\right)$ of intestinal circumference, considering the mesenteric insertion as $0^{\circ}$. Forty microscopic fields were sampled per animal. The field area was $0.224 \mathrm{~mm}^{2}$, resulting in a total area of $8.96 \mathrm{~mm}^{2}$.

The images of the myenteric neurons cell bodies were captured by high resolution camera, digitalized in a microcomputer and recorded in compact disc. The area $\left(\mu \mathrm{m}^{2}\right)$ of 100 cell bodies per segment, consisting in a total of 500 cell bodies per group, was measured using the image analysis software Image-Pro Plus 3.0.1. After variance analysis, we applied Student's t-test and Tukey's test to morphometric and quantitative data, respectively. Significance level was set at $5 \%$. All results were expressed as mean $(\mathrm{M}) \pm$ standard error (SE).

\section{RESULTS}

Initial and final body weight, glycemia, glycated hemoglobin and plasmatic level of ascorbic acid in the animals of the three groups studied are presented in Table I. All rats in groups D and DA were severely hyperglycemic $(\mathrm{p}<0.05)$ when compared to control group animals (Table I). Supplementation of group DA increased the plasmatic level of ascorbic acid in $62 \%$ in relation to group $\mathrm{D}(\mathrm{p}<0.05)$ and in $25.75 \%$ in relation to group $C(p>0.05)$ (Table I).

We did not observe evident differences in the neurons and ganglia morphology in three experiment groups under light microscopy (Fig. 1).

Fig. 2 shows the density of myenteric neurons stained according to Giemsa's technique, observed in the intermediate duodenal region of rats. Neuronal density in groups C, D and DA was $1711 \pm 132.4 ; 1154 \pm 55.31$ and $1378 \pm 97.85$ neurons, respectively, in an area of $8.96 \mathrm{~mm}^{2}$. We observed a significant $32.55 \%$ reduction in the neuronal density of group D when compared to group $C(p<0.05)$. It was also verified a $16.25 \%$ superior neuronal density in group $\mathrm{DA}$ in relation to group $\mathrm{D}(\mathrm{p}>0.05)$. 
Fig. 3 shows the mean area of neuronal cell bodies in the three experimental groups. There are no significant
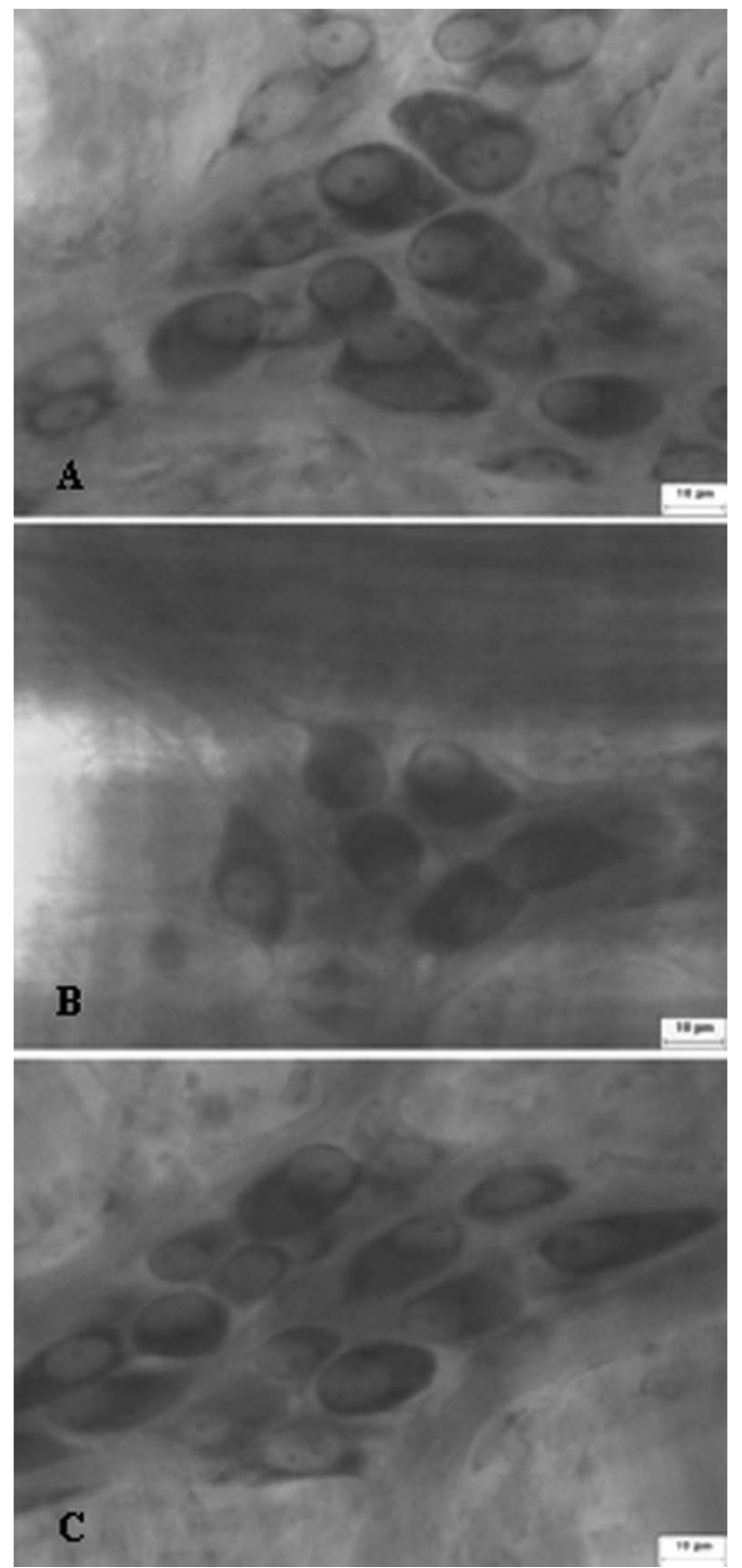

Figure1. Myenteric neurons of the duodenum of rats stained with Giemsa. Control (A), diabetics (B) and ascorbic acid treated diabetics $(\mathrm{C})$. Calibration bar $=10 \mu \mathrm{m}$. differences in the mean area of myenteric neurons cell bodies when all the groups are compared $(\mathrm{p}>0.05)$.

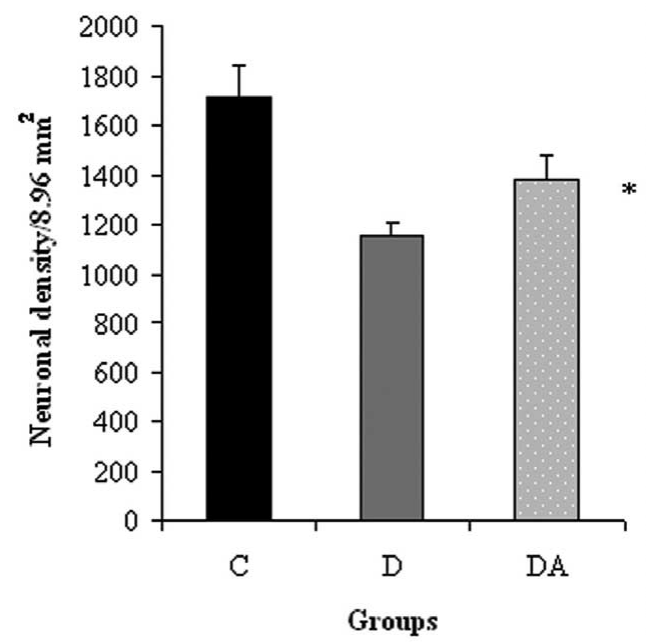

Fig. 2. Myenteric neurons, stained according to Giemsa's technique, observed in $8.96 \mathrm{~mm}^{2}$ from the duodenum of rats in groups: control (C), diabetic (D) and diabetic treated with ascorbic acid (DA). All results are expressed as mean \pm standard error. $\mathrm{n}=5$ rats per group. $* \mathrm{p}<0.05$ when compared to group $\mathrm{C}$.

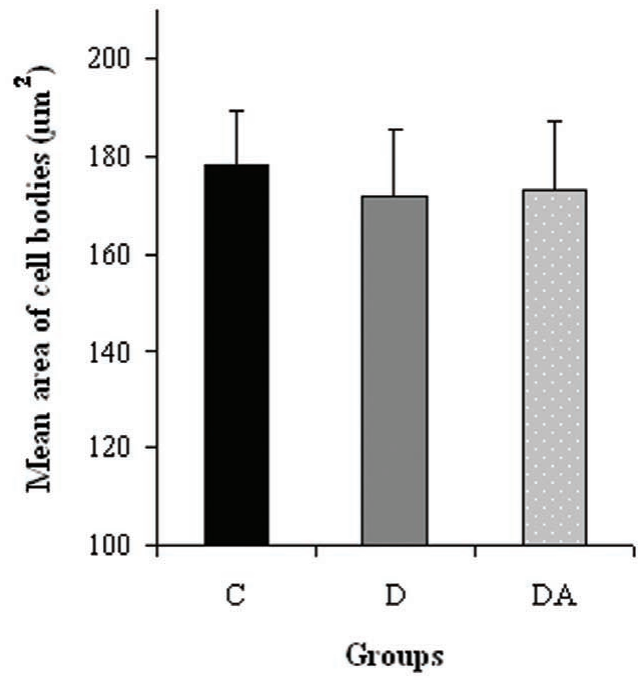

Fig. 3. Area of myenteric neurons cell bodies $(\mu \mathrm{m} 2)$. Groups: control (C), diabetic (D) and diabetic treated with ascorbic acid (DA). All results are expressed as mean \pm standard error. $p>0.05$ when all groups are compared.

Table I. Mean initial and final body weight (IBW and FBW), glycemia (GLY), glycated hemoglobin (GHb) and plasmatic ascorbic acid (PAA) in groups: control (C), diabetic (D) and diabetic treated with ascorbic acid (DA). All results are expressed as mean \pm standard error. $n=5$ rats per group. Means followed by different letters in the same column are statistically different according to Tukey's test $(\mathrm{p}<0.05)$.

\begin{tabular}{lccccc}
\hline & IBW $(\mathrm{g})$ & GLY $(\mathrm{mg} / \mathrm{dL})$ & GHb $(\%)$ & PAA $(\mu / \mathrm{mL})$ & FBW $(\mathrm{g})$ \\
\hline C & $339.4 \pm 12.36^{\mathrm{a}}$ & $129 \pm 3.9^{\mathrm{a}}$ & $4.1 \pm 0.3^{\mathrm{a}}$ & $24.58 \pm 5.5^{\mathrm{a}}$ & $456.2 \pm 14.57^{\mathrm{a}}$ \\
D & $329.6 \pm 8.49 \mathrm{a}$ & $466.4 \pm 24.6^{\mathrm{b}}$ & $8.1 \pm 0.2^{\mathrm{b}}$ & $12.6 \pm 1.9^{\mathrm{ab}}$ & $318.6 \pm 8.22^{\mathrm{b}}$ \\
DA & $339.0 \pm 12.45^{\mathrm{a}}$ & $493.0 \pm 10.1^{\mathrm{b}}$ & $7.9 \pm 0.5^{\mathrm{b}}$ & $33.1 \pm 2.5^{\mathrm{ac}}$ & $285.0 \pm 20.29^{\mathrm{b}}$ \\
\hline
\end{tabular}




\section{DISCUSSION}

In this experiment we employed Giemsa's technique. Based on that, our objective was to verify, after 120 days of diet supplementation, the possible protective effect of ascorbic acid (AA) on the overall myenteric neurons population from the duodenum of diabetic rats.

In our experiment, supplementation proved to be efficient once it elevated the plasmatic levels of ascorbic acid in $62 \%$ in group DA when related to group D and in $25.75 \%$ in group DA when related to group C. Ascorbic acid supplementation has been used in the treatment of diabetes neurological complications since it reduces the concentration of sorbitol by inhibiting aldose reductase, besides reducing capillary fragility and oxidative stress (Yue et al.; Cunningham et al.; Cotter et al.; Will \& Byers).

Plasmatic concentration of AA was found $48.7 \%$ reduced in animals of group $\mathrm{D}$ in relation to animals of group C. This reduction has been attributed to the greater exposure to oxidative stress that diabetic suffers (Young et al., 1992); to the elevated urinary excretion and to the hyperglycemia that inhibits AA transport into blood cells (Will \& Byers; Cunningham, 1998).

The neuronal density found in our control group (210-day-old), in an area of $8.96 \mathrm{~mm}^{2}$, was 1711 neurons (19095 neurons $/ \mathrm{cm}^{2}$ ), it is similar to the density of myenteric neurons stained as Giemsa's, reported by BorSeng-Shue et al. (1994) that quantified 20212 neurons/ $\mathrm{cm}^{2}$ in the duodenum of 5-month-old mice. It is also comparable to the studies of Natali et al. (2003) that found 21757 neurons $/ \mathrm{cm}^{2}$ when quantified the myenteric neurons in duodenum using the same technique and rats with the same age as ours (210-day-old). The difference in the neuronal density found by Natali et al. (1996) in 60-day-old control rats $\left(31438\right.$ neurons $\left./ \mathrm{cm}^{2}\right)$ and by Buttow et al. (1997) in 135-day-old rats (30843 neurons/ $\mathrm{cm}^{2}$ ), who also employed Giemsa's technique in duodenum, is due to the animals age.

Giemsa's technique was used aiming to stain the general neuronal population once that staining cell bodies was a result of the affinity of methylene blue by polyribosomes, organelles present in all nervous cells. We verified a reduction $(\mathrm{p}<0.05)$ in the density of myenteric neurons stained according to Giemsa's in group D when compared to group C. Our results in group $\mathrm{D}$ are similar to those reported by our research group, which verified myenteric neurons death after long periods of diabetes mellitus, as demonstrated in the colon (Romano et al.; Furlan et al.); in the cecum (Zanoni et al., 1997), in the ileum (Zanoni et al., 2003) and in the duodenum (Hernandes et al.; Pereira et al.).

The density of neurons spared from death in group DA was not significantly different in this experimental model $(\mathrm{p}>0.05)$. Similar results were found by Zanoni et al. (2003), that used the same model and demonstrated that AA supplementation did not significantly prevented the loss of general myosin- $\mathrm{V}$ immunoreactive myenteric neurons population from the ileum of diabetic rats treated with AA. However, following the same experimental model for myenteric neurons we demonstrated that the density of NADHdiaphorase subpopulation (Pereira et al.) and the areas of NADPH-diaphorase subpopulation (nitrergic neurons) (Zanoni et al., 2003) were protected in the duodenum and ileum of diabetic rats treated with ascorbic acid, respectively. Protection was also found in neurons that express the vasoactive intestinal peptide (VIP) in the submucous plexus from the ileum of treated diabetic animals, once we observed smaller cell bodies areas than those in diabetic animals (Zanoni et al., 2002).

Ascorbic acid supplementation avoided in $16.25 \%$ the reduction of density in the general population of myenteric neurons in group DA when compared to group D ( $>0.05)$. We believe that this percentage of preserved neuronal density is yet expressive if one considers that our results and those obtained by Zanoni et al. (2003) are originated of an experimental model formed by severely diabetic animals. Speculatively, it is possible that diabetic patients undergoing insulin treatment may present less severe stages of this syndrome and the concomitant use of AA in the treatment, for a longer period, may become more effective in the preservation of neuronal density. Further researches, with new experimental models, are necessary to document the protective effect of AA supplementation on the density of myenteric neurons general population in the small intestine of diabetic rats. This study leads us to conclude that diabetic rats presented a loss in the neuronal density when compared to control rats and that AA supplementation, considering this experiment dosage for a period of 120 days, did not preserved the density of myenteric neurons general population from the duodenum of diabetic rats treated with AA when in relation to untreated diabetic animals. 
PEREIRA, M. A. S.; LIBERATI, A. P.; SOUZA, I. D. S. \& ZANONI, J. N. Densidad y morfometría de la población total de las neuronas mientéricas del duodeno de ratones diabéticos (Rattus norvegicus) tratados con ácido ascórbico. Int. J. Morphol., 27(2):413418, 2009.

RESUMEN: El objetivo de este trabajo fue evaluar la población total de neuronas mientéricas del duodeno de ratones adultos inducidos a diabetes por estreptozotocina, suplementados con ácido ascórbico (AA), un poderoso antioxidante. Quince ratones con 90 días de edad fueron divididos en los grupos: control (C), diabético (D) y diabético tratados con ácido ascórbico (DA). Después de 120 días de tratamiento con AA, los duodenos fueron resecados y procesados con el método de Giemsa, el cual permitió evaluar la densidad neuronal, en un área de $8,96 \mathrm{~mm}^{2}$, y medir el área del soma de 500 neuronas por grupo. Se observó una reducción de 32,55\% de la densidad neuronal del grupo D con respecto grupo $\mathrm{C}(\mathrm{p}<0,05)$. La densidad de las neuronas observada en el grupo DA, en relación con el grupo D, no fue estadisticamente significativa en este modelo experimental. No fueron encontradas diferencias significativas en las áreas de neuronas, cuando los grupos C y D o el grupo D y DA ( $>0,05)$ fueron comparados. Nuestros resultados permitieron concluir que la densidad de la población total de las neuronas mioentéricas del duodeno estuvo reducida en los ratones diabéticos comparados con los controles, mientras que, los ratones diabéticos suplementados con AA no mantuvieron su densidad neuronal cuando fueron comparados con los animales del grupo diabético.

PALABRAS CLAVE: Ácido ascórbico; Diabetes mellitus; Duodeno; Estrés oxidativo.

\section{REFERENCES}

Barbosa, A. J. A. Técnica histológica para gânglios nervosos intramurais em preparados espessos. Rev. Bras. Med. Biol., 11(23):95-7, 1978.

Bor-Seng-Shu, E.; Chadi, G.; Bor-Jium-Shu, F.; Ferraz-deCarvalho, C. A. \& De Souza, R. R. Myenteric neurons of the mouse small intestine. Morphometry and acetylcolinesterase activity. Braz. J. Med. Biol. Res., 27:101-8, 1994.

Buttow, N. C.; Miranda-Neto, M. H. \& Bazotte, R. B. Morphological and quantitative study of the myenteric plexus of the duodenum of streptozotocin-induced diabetic rats. Arq. Gastroenterol., 34(1):34-42, 1997.

Cotter, M. A.; Love, A.; Watt, M. J.; Cameron, N. E. \& Dines, K. C. Effects of natural free radical scavengers on peripheral nerve and neurovascular function in diabetic rats. Diabetologia, 38:1285-94, 1995.

Cunningham, J. J. Micronutrients as nutriceutical interventions in diabetes mellitus. J. Am. Col. Nut., 17:7$10,1998$.

Cunningham, J. J.; Mearkle, P. L. \& Brown, G. Vitamin C: an aldose reductase inhibitor that normalizes erythrocyte sorbitol in insulin-dependent diabetes mellitus. J. Am. Col. Nut., 13:344-50, 1994.

Furlan, M. M. D.; Molinari, S. L. \& Miranda-Neto, M. H. Morphoquantitative effects of acute diabetes on the myenteric neurons of the proximal colon of adult rats. Arq. Neuropsiquiatr., 60:576-81, 2002.
Furness, J. B. \& Costa, M. The enteric nervous system. New York, Churchil Livingstone, 1987, p.289.

Gershon, M. D. The enteric nervous system. Ann. Rev. Neurosci., 4:227-72, 1981.

Hernandes, L.; Bazotte, R. B.; Gama. P. \& Miranda-Neto, M. Streptozotocin- induced diabetes duration is important to determine changes in the number and basophily of myenteric neurons. Arq. Neuropsiquiatr., 58:1035-9, 2000

Hosking, D. J.; Bennett, T. \& Hampton, D. M. Diabetic Autonomic Neuropathy. J. Am. Diet. Assoc., 27(10):1043-55, 1978.

Natali, M. R. M. \& Miranda-Neto, M. H. Effects of maternal proteic undernutrition on the neurons of the myenteric plexus of duodenum of rats. Arq. Neroupsquiatr., 54(2):273-9, 1996.

Natali, M. R. M; Miranda-Neto, H. M. \& Orsi, M. A. Morphometry and quantification of the myenteric neurons of the duodenum of rats fed with hypoproteic chow. Int. J. Morphol., 21(4):273-7, 2003.

Pereira, M. A. S.; Bagatin, M. C. \& Zanoni, J. N. Effects of the ascorbic acid supplementation on NADH-diaphorase myenteric neurons in the duodenum of diabetic rates, Biocell, 30(2):1-6, 2006.

Romano, E. B ; Miranda-Neto, M. H. \& Cardoso, R. C. Preliminary investigation about the effects of 
PEREIRA, M. A. S.; LIBERATI, A. P.; SOUZA, I. D. S. \& ZANONI, J. N. Density and morphometry of overall myenteric neurons population from the duodenum of diabetic rats (Rattus norvegicus) under ascorbic acid supplementation. Int. J. Morphol., 27(2):413-418, 2009.

streptozotocin induced chronic diabetes on the nerve cell number and size of myenteric ganglia in rat colon. Rev. Chil. Anat., 14(2):139-45, 1996.

Vincent, A. M.; Russell, J. W.; Low, P. \& Feldman, E. L. Oxidative stress in the pathogenesis of diabetic neuropathy. Endocrine Review, 25(4):612-28, 2004.

Will, J. C. \& Byers, T. Does diabetes mellitus increase the requirement for vitamin C? Nutritions Review, 54:193$202,1996$.

Young, I. S.; Torney, J. J. \& Trimble, E. R. The effect of ascorbate supplementation on oxidative stress in the streptozotocin diabetic rat. Free Radic. Biol. Med., 13:416, 1992 .

Yue, D. K.; Mclennan, S.; Fisher, E.; Heffernan, S.; Capogreco, C.; Roos, G. R. \& Turtle, J. R. Ascorbic acid metabolism and polyol pathway in diabetes. Diabetes, 38:257-61, 1989.

Zanoni, J. N.; Buttow, N. C.; Bazotte, R. B. \& MirandaNeto, M. H. Evaluation of the population of NADPHdiaphorase-stained and myosin- $\mathrm{V}$ myenteric neurons in the ileum of chronically streptozotocin-diabetic rats tested with ascorbic acid. Auton. Neurosci., 104:32-8, 2003.

Zanoni, J. N.; Hernandes, L.; Bazotte, R. B. \& MirandaNeto, M. H. Terminal ileum submucous plexus: Study of the VIP-ergic neurons diabetic rats treated whit ascorbic acid. Arq. Neuropsquiatr., 60:32-7, 2002.

Zanoni, J. N.; Miranda-Neto, M. H.; Bazotte, R. B. \& Souza, R. R. Morphological and quantitative analysis of the neurons of the myenteric plexus of the cecum of streptozotocin diabetic rats. Arq. Neuropsquiatr., 55(4):696-702, 1997.
Correspondence to:

Dra. Marli Aparecida dos Santos Pereira.

Universidade Estadual de Maringá, Departamento de Ciências Morfofisiológicas Bloco $\mathrm{H} 79$, sala 15.

Av. Colombo 5790, CEP 87020-900

Maringá, PR, Brazil.

Tel: +554432614705

Email: maspereira@uem.br

Received: 09-07-2008

Accepted: 22-01-2009 